\title{
Unexpected synthesis of 3,5-dimethyl-1-phenyl-1,5-dihydro-4H- pyrazolo[4,3-c]quinolin-4-one by non-classical Pschorr reaction, endowed with binding affinity for the central benzodiazepine receptor \\ Giuseppe Daidone ${ }^{a}$, Benedetta Maggio, ${ }^{a}$ Demetrio Raffa, ${ }^{* a}$ and Fiorella Meneghetti ${ }^{b}$ \\ ${ }^{a}$ Dipartimento di Scienze e Tecnologie Biologiche Chimiche e Farmaceutiche, Università degli Studi di Palermo, via Archirafi, 32, 90123-Palermo, Italy \\ ${ }^{b}$ Dipartimento di Scienze Farmaceutiche, Università di Milano, via L. Mangiagalli 25, 20133 Milano, Italy \\ E-mail: demetrio.raffa@unipa.it
}

DOI: $\underline{\text { http://dx.doi.org/10.3998/ark.5550190.0015.407 }}$

\begin{abstract}
The reaction of the diazonium salt 12 derived from $N$-(2-aminophenyl)- $N, 3$-dimethyl-1-phenyl$1 H$-pyrazole-5-carboxamide with copper sulfate and sodium chloride in the presence of ascorbic acid afforded the unexpected products 3,5-dimethyl-1-phenyl-1,5-dihydro-4H-pyrazolo[4,3-c]quinolin-4-one (17) and $N$-methyl-2-(3-methyl-1-phenyl-1H-pyrazol-5-yl)aniline (19), accompanied by $N$-(2-chlorophenyl)- $N, 3$-dimethyl-1-phenyl-1H-pyrazole-5-carboxamide (18). Products 17 and 19 are formed via a non-classical Pschorr reaction. The formation of 17 represents an alternative to the literature synthesis of this biologically active compound. The molecular structure of $\mathbf{1 8}$ was confirmed by single-crystal X-ray analysis.
\end{abstract}

Keywords: Pschorr, Sandmeyer reactions, 1,4-pyrazolyl transfer, fused pyrazoles, quinolines, 1,5-hydrogen transfer

\section{Introduction}

Hanson and coworkers have described the use of a combination of $\mathrm{CuSO}_{4}$ and $\mathrm{NaCl}$ in the presence of ascorbic acid to perform the Sandmeyer reaction of 4-chlorobenzenediazonium chloride in a homogeneous aqueous phase, leading to 1,4-dichlorobenzene. ${ }^{1}$ Ascorbic acid serves to reduce $\mathrm{Cu}(\mathrm{II})$ to $\mathrm{Cu}(\mathrm{I})$, which, in turn, reduces the diazonium ion to a diazenyl radical. The latter decomposes to dinitrogen and a 4-chlorophenyl radical. Complexes of $\mathrm{Cu}$ (II) ions with chloride ions then transfer chlorine to the 4-chlorophenyl radical to afford the final product. 
<smiles>Cc1cc(N(C)C(=O)c2ccccc2N)n(-c2ccccc2)n1</smiles>

1<smiles></smiles>

5<smiles>Cc1cc(N(C)C(=O)c2ccccc2[NH3+])n(-c2ccccc2)n1</smiles>

2<smiles>Cc1cc(N(C)C(=O)c2ccccc2Cl)n(-c2ccccc2)n1</smiles>

3

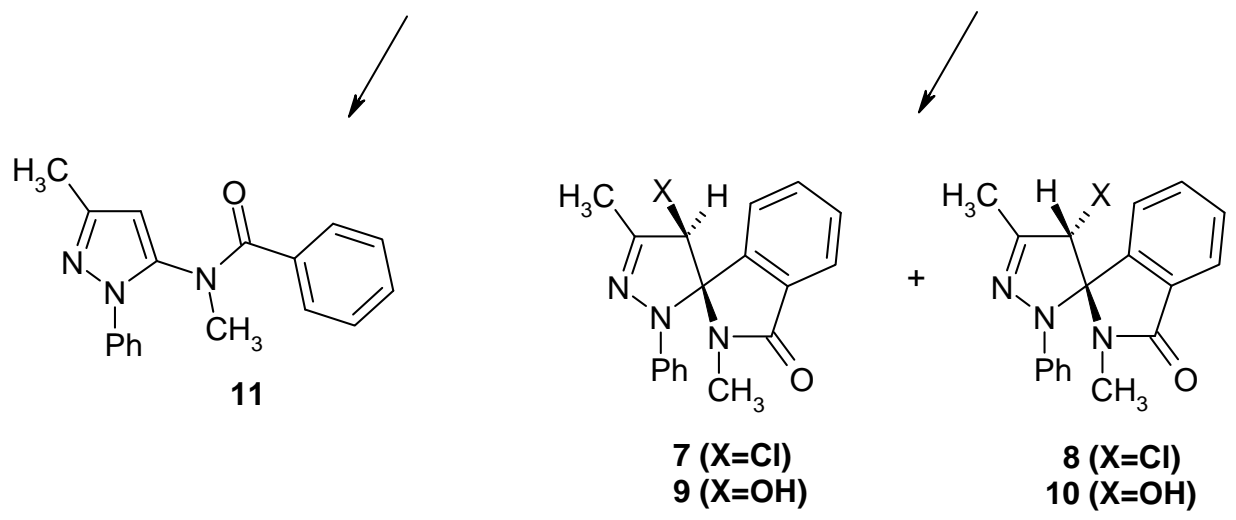

Scheme 1. i) $\mathrm{CuSO}_{4} /$ ascorbic acid / $\mathrm{NaCl}$.

We found earlier that, under the foregoing conditions, diazonium salt 2 affords neither the chloro derivative $\mathbf{3}$, the product of the classical Sandmeyer reaction, nor the tricyclic derivative 5, the expected product of a competing Pschorr ring closure, instead a mixture of epimeric products $\mathbf{7}$ and 8, derived presumably via radical intermediates $\mathbf{4}$ and 6, are the major reaction products (Scheme 1, only a couple of epimers is represented). ${ }^{2}$ We isolated also the derivative 11, formed via a 1,5-hydrogen atom transfer process, and trace amounts of the hydroxy spiro epimers 9 and $10{ }^{3}$ The formation of 7,8 and 9,10 may be considered as an example of consecutive non-classical Pschorr and Sandmeyer reactions. ${ }^{2}$

Continuing research on this reaction, ${ }^{2,4,5}$ we became interested in investigating the behaviour of substrates displaying an inverted amide bridge, that is, $-\mathrm{CONCH}_{3}$ - instead of $-\mathrm{NCH}_{3} \mathrm{CO}-$, between the pyrazole and phenyl rings, in order to verify whether such modification influences the course of the reaction. In fact, $-\mathrm{CONCH}_{3}$ - and $-\mathrm{NCH}_{3} \mathrm{CO}$ - groups exert opposite electronic effects on both the nuclei and may also influence the reactivity of radicals of the type $\mathbf{4}$ and $\mathbf{6}$. 
Here, we describe the decomposition of the diazonium hydrogen sulfate 12 (Fig. 1), exhibiting an inverted amide bridge, by $\mathrm{CuSO}_{4} /$ ascorbic acid in the presence of $\mathrm{NaCl}$.

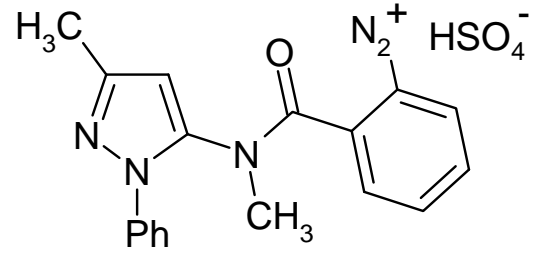

2

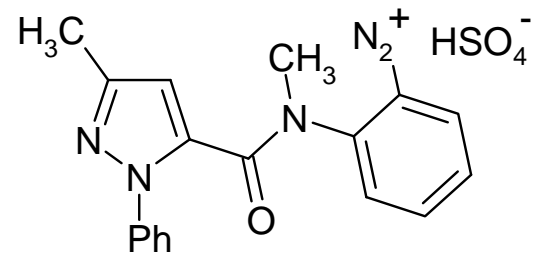

12

Figure 1. Diazonium hydrogen sulfates 2 and 12.

\section{Results and Discussion}

Treatment of 3-methyl-1-phenyl-1H-pyrazole-5-carboxylic acid with thionyl chloride gave the expected acyl chloride 13, which was condensed in situ with $N$-methyl-2-nitroaniline. The nitro group in the product 14 was reduced by hydrogenation in presence of $10 \%$ palladium on activated charcoal as a catalyst to give $N$-(2-aminophenyl)- $N, 3$-dimethyl-1-phenyl-1H-pyrazole5-carboxamide (15), diazotization of which produced the diazonium hydrogen sulfate 12. Exposure of the latter to $\mathrm{CuSO}_{4} / \mathrm{NaCl} /$ ascorbic acid as earlier seen with 2, afforded three compounds, namely: 3,5-dimethyl-1-phenyl-1,5-dihydro-4H-pyrazolo[4,3-c]quinolin-4-one (17), $N$-(2-chlorophenyl)- $N, 3$-dimethyl-1-phenyl-1H-pyrazole-5-carboxamide (18), and $N$-methyl-2(3-methyl-1-phenyl-1H-pyrazol-5-yl)aniline (19) (Scheme 2).

The structure of 17 was ascertained by comparison (mixed melting point, TLC, MS, IR, NMR) with an authentic sample, ${ }^{6}$ thus ruling out the isomeric structure 16, which could have formed from 12 through a Pschorr reaction pathway (see Schemes 2 and 3). The structure of 18 was confirmed by single-crystal X-ray analysis allowing a spiro structure of type 32 (Scheme 3 ) to be ruled out.

One difference in chemical behaviour between diazonium salts $\mathbf{1 2}$ and $\mathbf{2}$ is attributable to the fragmentation of radical intermediate 29, leading to the formation of carbamoyl radical $\mathbf{3 0}$. No such reaction pathway is available to radical $\mathbf{6}$ derived from the isomeric salt $\mathbf{2}$, as fragmentation presumably would produce an energetic radical (see Schemes 1 and 3). Pschorr-type ring closure of intermediate 30 produces compound 17, while loss of carbon monoxide and hydrogen atom transfer to the resulting aminyl radical afford the 1,5-diphenylpyrazole derivative 19 (Schemes 3 and 2). The transformation of $\mathbf{2 8}$ into $\mathbf{3 0}$ is an example of 1,4-pyrazolyl transfer from a carbonyl group to a phenyl radical. Another significant difference in chemical behaviour between diazonium salts 12 and $\mathbf{2}$ is the formation of the classical product of the Sandmeyer reaction exclusively from 12 (compound 18, Schemes 3 and 2). The above difference might be explained by assuming that radical $\mathbf{2 8}$ has a lifetime long enough to allow its reaction with the chloro- 
copper(II) complexes to give 18, whereas radical 4 converts readily into the stable radical 6 which, in turn, affords the epimers 7,8 and 9,10, as well as to compound $\mathbf{1 1}$ by a 1,5-hydrogen atom transfer process $^{3}$ (Scheme 1).<smiles>Cc1cc(C(=O)Cl)n(-c2ccccc2)n1</smiles>

13<smiles>Cc1cc(C(=O)N(C)c2ccccc2N)n(-c2ccccc2)n1</smiles>

$14(70 \%)$ $\downarrow \mathrm{H}_{2}, \mathrm{Pd} / \mathrm{C}$<smiles>[Y]C1(C)CCCC1</smiles>

16
$15(74 \%)$<smiles>Cc1cc(C(=O)N(C)c2ccccc2N)n(-c2ccccc2)n1</smiles>

12

$\downarrow i$<smiles>Cc1nn(-c2ccccc2)c2c1c(=O)n(C)c1ccccc21</smiles>

17 (20\%)<smiles>Cc1cc(C(=O)N(C)c2ccccc2Cl)n(-c2ccccc2)n1</smiles>

$18(7.55 \%)$<smiles>CNc1ccccc1-c1cc(C)nn1-c1ccccc1</smiles>

$19(10 \%)$

Scheme 2. i) $\mathrm{CuSO}_{4} /$ ascorbic acid/ $\mathrm{NaCl}$.

Lastly, we note that pyrazolo[4,3-c]quinoline $\mathbf{1 7}$ and congeners are of interest as agonists of the central benzodiazepine receptor. For instance, compound $\mathbf{1 7}$ itself displaces $\left[{ }^{3} \mathrm{H}\right]$ flunitrazepam from its receptor site in bovine brain membranes with a $\mathrm{IC}_{50}$ value of $3.4 \pm 0.2$ $\mu \mathrm{M}{ }^{6}{ }^{6}$ The preparation of $\mathbf{1 7}$ by reaction of the diazonium salt $\mathbf{1 2}$ with the $\mathrm{CuSO}_{4} /$ ascorbic acid system represents a valuable alternative to the synthetic method reported in literature. Furthermore, compound $\mathbf{1 7}$ has a planar structure, and as a consequence, it may be able to intercalate into the DNA double helix and express antiproliferative activity. Indeed, testing of $\mathbf{1 7}$ 
against the HL-60 (Human promyelocytic leukemia) cell line, revealed a $40 \%$ cell growth inhibition at a $10 \mu \mathrm{M}$ concentration.

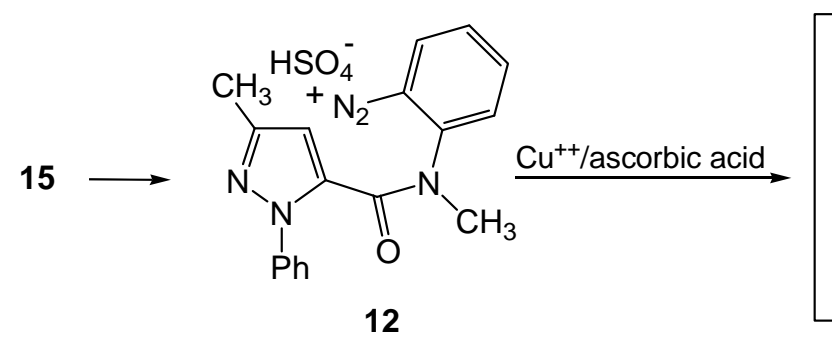

12

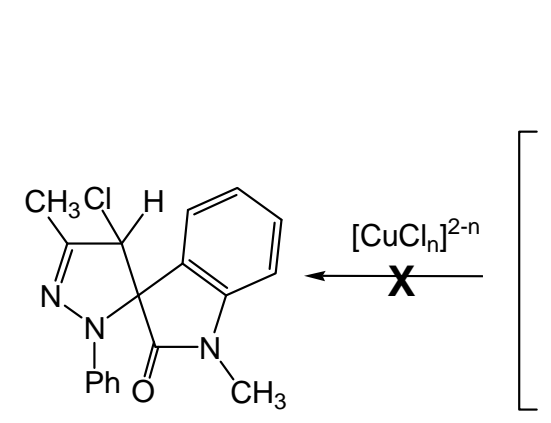

32<smiles>Cc1cc(C(=O)N(C)c2ccccc2)n(-c2ccccc2)n1</smiles>

28<smiles>Cc1nn(-c2ccccc2)c2c(=O)n(C)c3ccccc3c12</smiles>

16<smiles>Cc1cc(C(=O)N(C)c2ccccc2Cl)n(-c2ccccc2)n1</smiles>

29

18

$\downarrow$

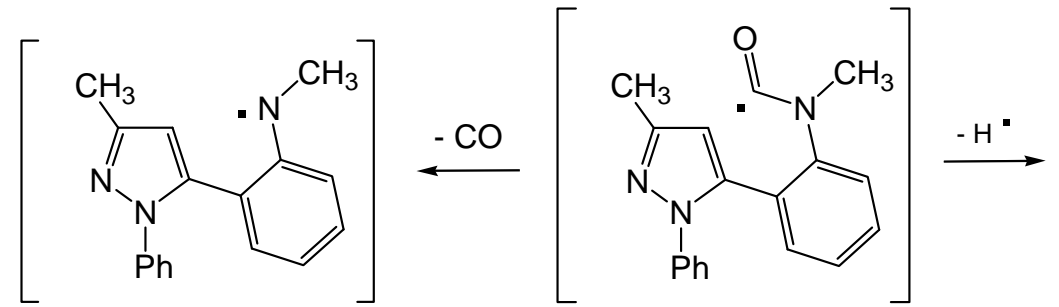

31

30<smiles>Cc1nn(-c2ccccc2)c2c1c(=O)n(C)c1ccccc21</smiles>

17<smiles>CNc1ccccc1-c1cc(C)nn1-c1ccccc1</smiles>

19

Scheme 3. Suggested mechanism for the transformation of $\mathbf{1 2 .}$ 


\section{Crystal structure of compound 18}

The crystal structure of $\mathbf{1 8}$ is shown in Figure 2 as ORTEP $^{7}$ view.

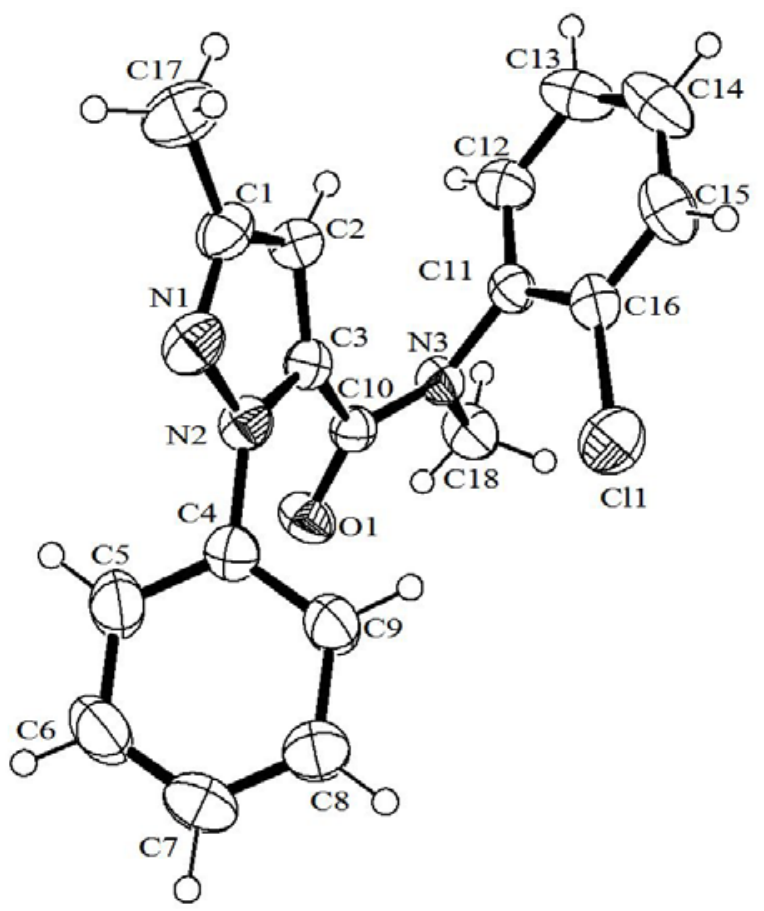

Figure 2. ORTEP ${ }^{7}$ drawing of $\mathbf{1 8}$ with the atom numbering scheme (ellipsoids are at $50 \%$ probability).

The overall conformation of the molecule is defined by the torsion angles C5-C4-N2-N1 of $66.4(3)^{\circ}$ and $\mathrm{C} 10-\mathrm{N} 3-\mathrm{C} 11-\mathrm{C} 16$ of $69.2(3)^{\circ}$ that indicate a significant tilting of the phenyl moieties with respect to the rest of the molecule. This is best evidenced by the dihedral angles of $66.1(1)^{\circ}$ and $75.1(1)^{\circ}$ between the pyrazole with the phenyl and $o$-chlorophenyl rings, respectively, while the dihedral angle between the two benzene is $38.7(1)^{\circ}$. The geometrical parameters show the presence of an electronic delocalization in the whole molecule. In particular, the short distance found between $\mathrm{C} 3$ and $\mathrm{C} 11$ suggests the presence of a resonance effect across the $\mathrm{C}-\mathrm{C}$ bond linked to the amide fragment. In addition, the $\mathrm{N}-\mathrm{C}_{\text {phenyl }}$ bond distances are shorter than those of the $\mathrm{N}-\mathrm{C}_{\text {methyl }}$, indicating that the orientation of the phenyl rings slightly influences the conjugative effect on the respective adjacent bond of the moiety to which they are linked. This is in agreement with our previously published results. ${ }^{4}$

In the crystals, the molecules are connected by weak intermolecular $\mathrm{C} \pi-\mathrm{H} \ldots \mathrm{O}$ type interactions, as shown in Figure 3. These contacts involve C12-H12...O ${ }^{\mathrm{I}}$ ( ${ }^{\mathrm{I}}$ at $1 / 2-\mathrm{x}, \mathrm{y}+1 / 2,3 / 2-$ z) at a distance of 2.57(1) $\AA$, angle $166(1)^{\circ}$, and C6-H6...O $1^{\mathrm{II}}$ ( ${ }^{\mathrm{II}}$ at $-\mathrm{x},-\mathrm{y}+1,-\mathrm{z}+1$ ), at a distance of 2.62(1) $\AA$, angle $162(1)^{\circ}$, giving rise to a two-dimensional molecular arrangement. 


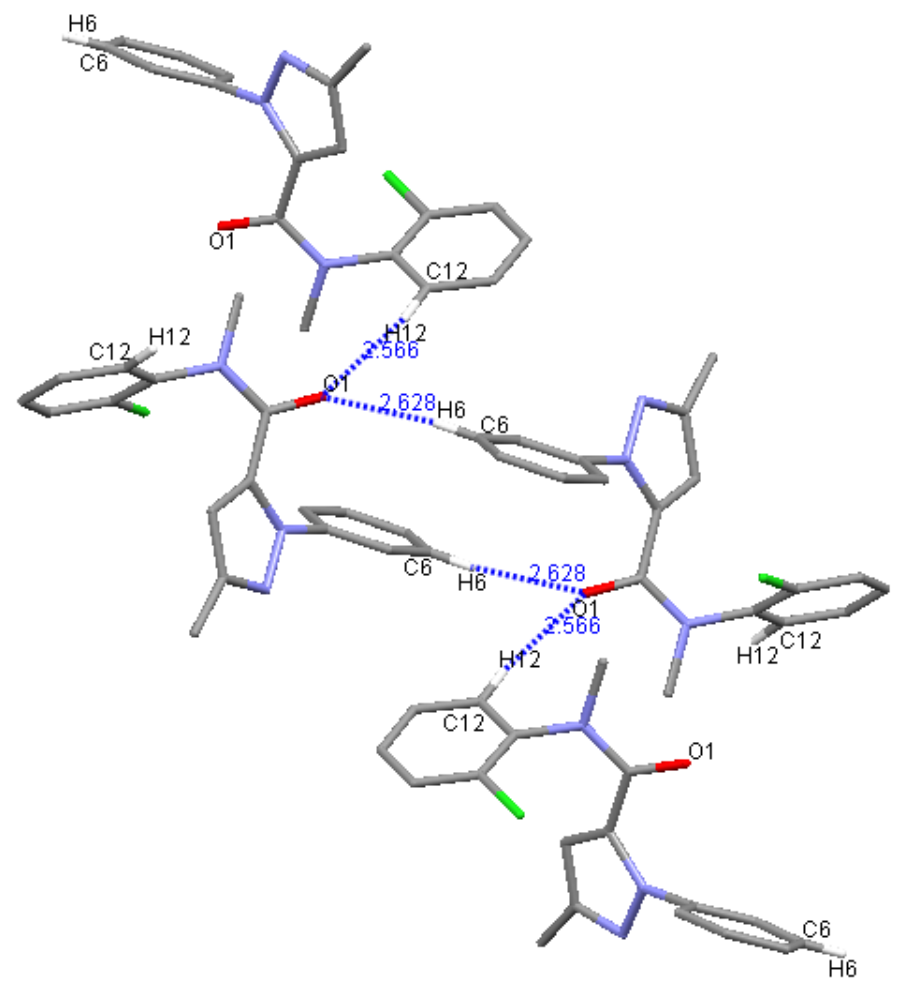

Figure 3. Intermolecular interactions (in dashed lines) of $\mathbf{1 8}$ viewed along the $b$ axis. For the sake of clarity, only the hydrogen atoms involved in $\mathrm{C} \pi-\mathrm{H}$... O contacts are represented.

\section{Conclusions}

The product distribution observed in the reaction of the copper sulfate/ascorbic acid/sodium chloride system with the isomeric diazonium salts 2 and 12, wherein the amide bridge that links the pyrazole and benzene rings is inverted, differs significantly as a consequence of different lifetimes of radicals $\mathbf{2 8}$ and $\mathbf{4}$ as well as of the distinct chemical reactivity of radical intermediates $\mathbf{2 9}$ and $\mathbf{6}$.

\section{Experimental Section}

\section{Chemistry}

General. Reaction progress was monitored by TLC on silica gel plates (Merck 60, $\mathrm{F}_{254}, 0.2 \mathrm{~mm}$ ). Organic solutions were dried over $\mathrm{Na}_{2} \mathrm{SO}_{4}$. Evaporation refers to the removal of solvent on a rotary evaporator under reduced pressure. All melting points were determined on a Büchi 530 capillary melting point apparatus and are uncorrected. IR spectra were recorded with a Perkin Elmer Spectrum RXI FT-IR System spectrophotometer as solids in $\mathrm{KBr}$ discs. ${ }^{1} \mathrm{H}-\mathrm{NMR}$ and ${ }^{13} \mathrm{C}$ - 
NMR spectra were obtained in $\mathrm{CDCl}_{3}$ at 300.13 and $75.47 \mathrm{MHz}$ respectively, using a Bruker $\mathrm{AC}$ series $300 \mathrm{MHz}$ spectrometer (tetramethylsilane as an internal standard): chemical shifts are expressed in $\delta$ values (ppm). Mass spectra at $70 \mathrm{eV}$ were obtained using an Autospec Ultima Orthogonal T.O.F.T. (Micromass) spectrometer. Merck silica gel (Kiesegel 60/230-400 mesh) was used for flash chromatography columns. Microanalysis data $(\mathrm{C}, \mathrm{H}, \mathrm{N})$ were obtained by an Elemental Vario EL. III apparatus. Yields refer to products obtained after one crystallization.

3-Methyl-1-phenyl-1H-pyrazole-5-carbonyl chloride (13). 3-Methyl-1-phenyl-1H-pyrazole-5carboxylic $\operatorname{acid}^{8}(2.22 \mathrm{~g}, 11 \mathrm{mmol})$ was reacted with $\mathrm{SOCl}_{2}(8 \mathrm{ml})$ under reflux for $5 \mathrm{~h}$. The solution was evaporated under reduced pressure and the brown oily residue obtained was used in the next step.

$N$,3-Dimethyl- $N$-(2-nitrophenyl)-1-phenyl-1H-pyrazole-5-carboxamide (14). A solution containing 13 obtained as above and $N$-methyl-2-nitroaniline $(3.34 \mathrm{~g}, 22 \mathrm{mmol})$ in dry acetonitrile $(50 \mathrm{ml})$ was refluxed for $10 \mathrm{~h}$. The solution was evaporated under reduced pressure, and the residue was washed with ethyl ether $(2 \times 10 \mathrm{ml})$ and then crystallized from ethyl acetate/ light petroleum ether (b.p. $40-70{ }^{\circ} \mathrm{C}$ ) to give 14 , as a pale yellow solid, in $70 \%$ yield (referred to to 3-Methyl-1-phenyl-1H-pyrazole-5-carboxylic acid), $2.6 \mathrm{~g}, \mathrm{mp}: 150-52{ }^{\circ} \mathrm{C} . \mathrm{MS}(\mathrm{m} / \mathrm{z}): 336$ $\left(\mathrm{M}^{+}\right)$. IR $\left(v_{\max }, \mathrm{cm}^{-1}\right): 1660(\mathrm{CO}) .{ }^{1} \mathrm{H}-\mathrm{NMR}: \delta_{\mathrm{H}} 2.16(3 \mathrm{H}, \mathrm{s}, \mathrm{Me}), 3.36(3 \mathrm{H}, \mathrm{s}, \mathrm{Me}), 6.00(1 \mathrm{H}, \mathrm{s}$, pyrazole $\mathrm{H}-\mathrm{C}(4))$, $7.26-8.03\left(9 \mathrm{H}, \mathrm{m}, \mathrm{C}_{6} \mathrm{H}_{5}\right.$ and $\left.\mathrm{C}_{6} \mathrm{H}_{4}\right)$; Anal. Calcd. for $\mathrm{C}_{18} \mathrm{H}_{16} \mathrm{~N}_{4} \mathrm{O}_{3}(336.34)$ : C, 64.28; H, 4.79; N, 16.66. Found: C, 64.28; H, 4.99; N, 16.90\%.

(2-Aminophenyl)- $N$,3-dimethyl-1-phenyl-1H-pyrazole-5-carboxamide (15). A solution of 14 $(2.49 \mathrm{~g}, 7.4 \mathrm{mmol})$ in ethanol $(250 \mathrm{ml})$ was mixed with $0.5 \mathrm{~g}$ of $10 \%$ palladium on activated charcoal as a catalyst and shaken in a Parr apparatus under 45-50 psi of hydrogen for $24 \mathrm{~h}$. Filtration to separate the catalyst and evaporation under vacuum of the solvent yielded a residue which was crystallized from ethyl acetate to give (2-aminophenyl)- $N, 3$-dimethyl-1-phenyl- $1 H$ pyrazole-5-carboxamide 15, as a colourless solid, in 74\% yield, $1.7 \mathrm{~g}, \mathrm{mp}: 113-114{ }^{\circ} \mathrm{C}$. MS $(\mathrm{m} / \mathrm{z}): 306\left(\mathrm{M}^{+}\right)$. I.R. $\left(v_{\max }, \mathrm{cm}^{-1}\right): 3436$ and $3334\left(\mathrm{NH}_{2}\right), 1646(\mathrm{CO}) .{ }^{1} \mathrm{H}-\mathrm{NMR}: \delta_{\mathrm{H}} 2.18(3 \mathrm{H}, \mathrm{s}$, $\mathrm{Me}), 3.22(3 \mathrm{H}, \mathrm{s}, \mathrm{Me}), 3.33\left(2 \mathrm{H}, \mathrm{s}\right.$, exchangeable with $\left.\mathrm{D}_{2} \mathrm{O}, \mathrm{NH}_{2}\right), 6.12(1 \mathrm{H}, \mathrm{s}$, pyrazole $\mathrm{H}-\mathrm{C}(4))$, 6.51-7.44 $\left(9 \mathrm{H}, \mathrm{m}, \mathrm{C}_{6} \mathrm{H}_{5}\right.$ and $\left.\mathrm{C}_{6} \mathrm{H}_{4}\right) .{ }^{13} \mathrm{C}-\mathrm{NMR}: \delta_{\mathrm{C}} 13.35\left(\mathrm{CH}_{3}\right), 35.37\left(\mathrm{CH}_{3}\right), 108.72(\mathrm{CH})$, $116.29(\mathrm{CH}), 118.78(\mathrm{CH}), 124.10(\mathrm{CH}), 127.65(\mathrm{CH}), 128.35(\mathrm{C}), 128.41(\mathrm{CH}), 129.00(\mathrm{CH})$, $129.26(\mathrm{CH}), 137.09$ (C), 140.41 (C), 142.50 (C), 148.80 (C), 163.34 (CO); Anal. Calcd. for $\mathrm{C}_{18} \mathrm{H}_{18} \mathrm{~N}_{4} \mathrm{O}$ (306.36) : C, 70.57; H, 5.92; N, 18.29. Found: C, 70.82; H, 6.20; N, 18.59\%.

2-(N,3-Dimethyl-1-phenyl-1H-pyrazole-5-carboxamido)benzenediazonium hydrogen sulfate (12). The pulverized amine $15(0.998 \mathrm{~g}, 3.26 \mathrm{mmol})$ was dissolved in cooled $\left(0-5{ }^{\circ} \mathrm{C}\right) 2.5 \mathrm{~mol}$ $\mathrm{dm}^{-3}$ aqueous sulfuric acid $(6.5 \mathrm{ml})$, and $2.5 \mathrm{~mol} \mathrm{dm}^{-3}$ aqueous sodium nitrite $(1.34 \mathrm{ml})$ was added drop wise to the stirred solution. The solution was stirred for a further $15 \mathrm{~min}$ in the ice bath and then checked with potassium iodide starch paper for excess of nitrous acid; the eventual excess can be destroyed by addition of urea.

Decomposition of the diazonium hydrogen sulphate 12 . To a cold $(0-5 \mathrm{C}) \mathrm{soln}$. (170 $\mathrm{ml})$ of $\mathrm{CuSO}_{4} 5 \mathrm{H}_{2} \mathrm{O}(0.3 \mathrm{M})$ and $\mathrm{NaCl}(0.75 \mathrm{M})$, first the soln. of 12 obtained from the previous 
procedure, and then ascorbic acid $(140 \mathrm{mg}, 0.795 \mathrm{mmol})$ were added under stirring. The mixture was stirred for $1 \mathrm{~h}$ at r.t. and then filtered. The solid product obtained was dried in a desiccator (anhydrous $\mathrm{CaCl}_{2}$ ) for $24 \mathrm{~h}$ and then processed by flash chromatography ${ }^{9}$ (external diameter of the column $5.5 \mathrm{~cm}$, silica gel $(0.040-0.063 \mathrm{~mm}, 170 \mathrm{~g})$, ethyl ether/light petroleum ether (b.p. $40-70{ }^{\circ} \mathrm{C}$ ) 1:1 as eluent; fractions $50 \mathrm{ml}$ each. The initial eleven fractions were discarded and fractions 12-19 were evaporated under reduced pressure to give $125 \mathrm{mg}$ of a mixture that was crystallized from petroleum ether (b.p. $100-140{ }^{\circ} \mathrm{C}$ ) to give $\mathrm{N}$-methyl-2-(3-methyl-1-phenyl-1Hpyrazol-5-yl)aniline (19) as a colourless solid, in $10 \%$ yield, $85.8 \mathrm{mg}, \mathrm{mp}: 109-110{ }^{\circ} \mathrm{C}$. MS $(\mathrm{m} / \mathrm{z}): 263\left(\mathrm{M}^{+}\right)$. IR $\left(v_{\max }, \mathrm{cm}^{-1}\right): 3411(\mathrm{NH}) .{ }^{1} \mathrm{H}-\mathrm{NMR}: \delta_{\mathrm{H}} 2.41(3 \mathrm{H}, \mathrm{s}, \mathrm{Me}), 2.75(3 \mathrm{H}, \mathrm{s}, \mathrm{Me})$, $4.00\left(1 \mathrm{H}, \mathrm{s}\right.$, exchangeable with $\left.\mathrm{D}_{2} \mathrm{O}, \mathrm{NH}\right), 6.29(1 \mathrm{H}, \mathrm{s}$, pyrazole $\mathrm{H}-\mathrm{C}(4))$, 6.57-7.29 (9H, m, $\mathrm{C}_{6} \mathrm{H}_{5}$ and $\mathrm{C}_{6} \mathrm{H}_{4}$ ); Anal. Calcd. for $\mathrm{C}_{17} \mathrm{H}_{17} \mathrm{~N}_{3}$ (263.34) : C, 77.54; H, 6.51; N, 15.96. Found: $\mathrm{C}$, 77.30; H, 6.40; N, 15.80\%.

Frs 22-31 were evaporated under vacuum and the residue $(110 \mathrm{mg})$ was crystallized from petroleum ether (b.p. $100-140{ }^{\circ} \mathrm{C}$ ) to give $N$-(2-chlorophenyl)- $N, 3$-dimethyl-1-phenyl-1Hpyrazole-5-carboxamide (18) as a colourless solid, in $7.55 \%$ yield, $80 \mathrm{mg}, \mathrm{mp}: 114-17{ }^{\circ} \mathrm{C}$. MS $(\mathrm{m} / \mathrm{z}): 325\left(\mathrm{M}^{+}\right)$. IR $\left(v_{\max }, \mathrm{cm}^{-1}\right): 1655(\mathrm{CO}) .{ }^{1} \mathrm{H}-\mathrm{NMR}: \delta_{\mathrm{H}} 2.15(3 \mathrm{H}, \mathrm{s}, \mathrm{Me}), 3.28(3 \mathrm{H}, \mathrm{s}, \mathrm{Me})$, $5.98(1 \mathrm{H}, \mathrm{s}$, pyrazole $\mathrm{H}-\mathrm{C}(4)), 6.69-7.46\left(9 \mathrm{H}, \mathrm{m}, \mathrm{C}_{6} \mathrm{H}_{5}\right.$ and $\left.\mathrm{C}_{6} \mathrm{H}_{4}\right) .{ }^{13} \mathrm{C}-\mathrm{NMR}: \delta_{\mathrm{C}} 13.30\left(\mathrm{CH}_{3}\right)$, $36.51\left(\mathrm{CH}_{3}\right), 108.84(\mathrm{CH}), 123.94(2 \times \mathrm{CH}), 127.60(\mathrm{CH}), 127.71(\mathrm{CH}), 128.93(2 \times \mathrm{CH}), 128.48$ $(\mathrm{CH}), 129.54(\mathrm{CH}), 130.44(\mathrm{CH}), 132.53(\mathrm{C}), 136.80(\mathrm{C}), 140.21(\mathrm{C}), 140.27$ (C), $148.60(\mathrm{C})$, 162.23 (CO); Anal. Calcd. for $\mathrm{C}_{18} \mathrm{H}_{16} \mathrm{ClN}_{3} \mathrm{O}$ (325.79) : C, 66.36; H, 4.95; N, 12.90. Found: C, 66.56; H, 4.70; N, $12.65 \%$.

Frs 49-61 were evaporated under vacuum, and the residue $(370 \mathrm{mg})$ was crystallized from ethanol $(95 \% \mathrm{v} / \mathrm{v})$ to give a colourless solid in $20 \%$ yield, $189 \mathrm{mg}$, identicall in all respect (mixed melting point, TLC, MS, 1H NMR, 13C NMR, IR) to a authentic specimen of 3,5-dimethyl-1phenyl-1,5-dihydro-4H-pyrazolo[4,3-c]quinolin-4-one ${ }^{6}$ (17), mp 187-88 ${ }^{\circ} \mathrm{C}$. MS (m/z): $289\left(\mathrm{M}^{+}\right)$. IR $\left(v_{\max }, \mathrm{cm}^{-1}\right): 1657(\mathrm{CO}) .{ }^{1} \mathrm{H}-\mathrm{NMR}: \delta_{\mathrm{H}} 2.76(3 \mathrm{H}, \mathrm{s}, \mathrm{Me}), 3.75(3 \mathrm{H}, \mathrm{s}, \mathrm{Me}), 6.94-7.60(9 \mathrm{H}, \mathrm{m}$, $\mathrm{C}_{6} \mathrm{H}_{5}$ and $\left.\mathrm{C}_{6} \mathrm{H}_{4}\right) .{ }^{13} \mathrm{C}-\mathrm{NMR}: \delta_{\mathrm{CL}} 13.27\left(\mathrm{CH}_{3}\right), 29.00\left(\mathrm{CH}_{3}\right), 111.32(\mathrm{C}), 112.18(\mathrm{C}), 115.60(\mathrm{CH})$, $121.56(\mathrm{CH}), 123.13(\mathrm{CH}), 127.16(2 \mathrm{xCH}), 129.66(\mathrm{CH}), 129.77(2 \mathrm{xCH}), 129.89(\mathrm{CH})$, 136.8139.720 (C), $140.36(\mathrm{C}), 140.45$ (C), 149.38 (C), 159.62 (CO).

\section{Crystallography}

Crystals of 18 suitable for X-ray crystallography were grown by slow evaporation of petroleum ether solutions (b.p. $100-140^{\circ} \mathrm{C}$ ). They were mounted on an Enraf Nonius CAD-4 diffractometer using Mo-K $\alpha(\lambda=0.71073 \AA)$ radiation at $293(2) \mathrm{K}$. The lattice parameters were determined by least-squares refinements of 25 high angle reflections. The structure was solved by direct methods $^{10}$ and the refinements were carried out by full-matrix least-squares with SHELX-97

package $^{11}$ and WINGX ${ }^{12}$. All non-H-atoms were refined anisotropically. Hydrogen atoms were detected in a difference Fourier synthesis and refined with isotropic thermal factors. Geometrical calculations were carried out using the program PARST. ${ }^{13}$ 
The crystallographic data were deposited with the Cambridge Crystallographic Data Centre (CCDC deposition number 822400). Copies can be obtained gratis from CCDC, 12 Union Road, Cambridge CB2 1EZ, UK; fax: +44(1223) 336033; e-mail: deposit@ccdc.cam.ac.uk).

Crystal data for 18. $\mathrm{C}_{18} \mathrm{H}_{16} \mathrm{ClN}_{3} \mathrm{O}, \mathrm{M}_{\mathrm{r}}=325.80 \mathrm{~g} \mathrm{~mol}^{-1}$, Monoclinic, Space group $\mathrm{P} 2{ }_{1} / \mathrm{n}, \mathrm{a}=$ 13.958(1) $\AA, b=7.210(6) \AA, c=16.433(4) \AA, \beta=97.81(1)^{\circ}, V=1638(1) \AA^{3}, Z=4, D_{c}=1.321$ $\mathrm{Mg} \mathrm{m}^{-3}, \mathrm{R}=0.039$ (3754 reflections), $\mathrm{wR}_{2}=0.089, \mathrm{~T}=293(2) \mathrm{K}, \mathrm{GOF}=1.023$. The reflections were collected in the range $2.06^{\circ} \leq \theta \leq 24.98^{\circ}$ employing a $0.9 \times 0.8 \times 0.7 \mathrm{~mm}$ crystal.

\section{Biology}

Antiproliferative activity in vitro. Compound $\mathbf{1 7}$ was tested in vitro for antileukemic activity against HL-60 (Human promyelocytic leukemia) cell line. The cells were grown at $37{ }^{\circ} \mathrm{C}$ in a humidified atmosphere containing 5\% $\mathrm{CO}_{2}$, in RPMI-1640 medium (Biochrom $\mathrm{KG}$ ) supplemented with $10 \%$ fetal calf serum and antibiotics. Cells were suspended at a density of $2 \mathrm{X} 10^{5}$ cells per $\mathrm{ml}$ in growth medium, transferred to 24 -well plate $(1 \mathrm{ml}$ per well), cultured with or without (control wells) screening concentration of compound and incubated at $37{ }^{\circ} \mathrm{C}$ for $48 \mathrm{~h}$. Control wells were added with DMSO used to dissolve the compound to exclude a solvent activity. Numbers of viable cells were determined by counting in a hematocytometer after dye exclusion with trypan blue ${ }^{14}$. We determined at a concentration of $10 \mu \mathrm{M}$ the $\%$ of growth inhibition than the untreated growth control.

\section{Acknowledgements}

We are grateful to the Ministero dell'Istruzione dell'Università e della Ricerca (MIUR, Research fund ex 60\%) for financial support. We thank also Dr. Domenico Schillaci for the antiproliferative evaluation of compound $\mathbf{1 7 .}$

\section{References}

1. Hanson, P.; Jones, J. R.; Gilbert, B. C.; Timms, A. W. J. Chem. Soc., Perkin Trans. 2 1991, 1009-1017.

http://dx.doi.org/10.1039/p29910001009

2. Daidone, G.; Maggio, B.; Raffa, D.; Plescia, S.; Benetollo, F.; Bombieri, G. J. Chem. Soc., Perkin Trans. 1 1998, 2891-2897.

3. Maggio, B.; Raffa, D.; Raimondi, M. V.; Daidone, G. Molecules 2013, 18, 13096-13110. http://dx.doi.org/10.3390/molecules181013096

PMid:24152597

4. Maggio, B.; Daidone, G.; Raffa, D.; Plescia, S.; Bombieri, G.; Meneghetti, F. Helv. Chim. Acta 2005, 88, 2272-2281. 
http://dx.doi.org/10.1002/hlca.200590161

5. Maggio, B.; Raffa, D.; Raimondi, M. V.; Cascioferro S.; Plescia, S.; Sabatino, M. A.; Bombieri, G.; Meneghetti, F.; Daidone, G. Arkivoc 2008, 16, 130-143. http://dx.doi.org/10.3998/ark.5550190.0009.g13

6. Melani, F.; Cecchi, L.; Palazzino, G.; Filacchione, G.; Martini, C.; Pennacchi, E.; Lucacchini A. J. Med. Chem. 1986, 29, 291-295. http://dx.doi.org/10.1021/jm00152a019

7. Johnson, C. K. ORTEP II, Report ORNL-5138, Oak Ridge National Laboratory, TN, 1976.

8. Finar, I. L.; Hurlock, R. J. J. Chem. Soc. 1958, 3259-3263. http://dx.doi.org/10.1039/jr9580003259

9. Still, W. C.; Kahn, M.; Mitra, A. J. Org. Chem. 1978, 43, 2923-2925. http://dx.doi.org/10.1021/jo00408a041

10. Altomare, A.; Cascarano, G.; Giacovazzo, C.; Guagliardi, A. J. Appl. Crystallogr. 1993, 26, 343-350. http://dx.doi.org/10.1107/S0021889892010331

11. Sheldrick, G. M. SHELX-97, University of Göttingen, Germany

12. WinGX, Farrugia, J. L. J. Appl. Cryst. 1999, 32, 837. http://dx.doi.org/10.1107/S0021889899006020

13. Nardelli, M. J. Appl. Crystallogr. 1995, 28, 659. http://dx.doi.org/10.1107/S0021889895007138

14. Manfredini, S.; Bazzanini, R.; Baraldi, P.G.; Guarneri M.; Simoni, D.; Marongiu, M.E.; Pani, A.; Tramontano, E.; La Colla, P. J. Med. Chem. 1992, 35, 917-924. http://dx.doi.org/10.1021/jm00083a017 